Int. J. Mol. Sci. 2002, 3, 937-947

International Journal of

Molecular Sciences

ISSN 1422-0067

(C) 2002 by MDPI

www.mdpi.org/ijms/

\title{
Effect of Organic Solvents and Biologically Relevant Ions on the Light-Induced DNA Cleavage by Pyrene and Its Amino and Hydroxy Derivatives
}

\author{
Shiming Dong ${ }^{1}$, Shuguang Wang ${ }^{1}$, Gernerique Stewart ${ }^{1}$, Huey-Min Hwang ${ }^{2}$, Peter P. Fu ${ }^{3}$, \\ Hongtao $\mathrm{Yu}^{1^{*}}$ \\ ${ }^{1}$ Department of Chemistry, Jackson State University, Jackson, MS 39217, USA \\ ${ }^{2}$ Department of Biology, Jackson State University, Jackson, MS 39217, USA \\ ${ }^{3}$ National Center for Toxicological Research, Jefferson, AR 72079, USA \\ *Corresponding Author: Department of Chemistry, Jackson State University, Jackson, MS 39217 , \\ USA; Phone: (601)979-3727; Fax: (601)979-3674. Email: yu@jsums.edu
}

Received: 7 June 2002 / Accepted: 15 August 2002 / Published: 30 September 2002

\begin{abstract}
Polycyclic aromatic hydrocarbons (PAHs) are a class of carcinogenic compounds that are both naturally and artificially produced. Many PAHs are pro-carcinogens that require metabolic activation. Recently, it has been shown that PAH can induce DNA single strand cleavage and formation of PAH-DNA covalent adduct upon irradiation with UVA light. The light-induced DNA cleavage parallels phototoxicity in one instance. The DNA photocleavage efficiency depends on the structure of the PAHs. This article reports the effect of both organic solvents and the presence of biologically relevant ions, $\mathrm{Na}^{+}, \mathrm{Mg}^{2+}, \mathrm{Ca}^{2+}$, $\mathrm{K}^{+}, \mathrm{Fe}^{3+}, \mathrm{Cu}^{2+}, \mathrm{Zn}^{+2}, \mathrm{Mn}^{2+}$, and $\mathrm{I}^{-}$, on the light-induced DNA cleavage by pyrene, 1hydroxypyrene and 1-aminopyrene. Since both 1-hydroxypyrene $(0.6 \mu \mathrm{M})$ and 1aminopyrene $(6 \mu \mathrm{M})$ dissolve well in the minimum organic solvents used $(2 \%$ methanol, dimethylsulfoxide, and dimethylformamide), increasing the amount of the organic solvent resulted in the decrease of the amount of DNA single strand cleavage caused by the combination effect of 1-hydroxy or 1-aminopyrene and UVA light. The result with the less watersoluble pyrene shows that increase of the amount of the organic solvent can increase the amount of DNA single strand DNA photocleavage cause by the combination of pyrene and UVA light. Therefore, there are two effects by the organic solvents: (i) to dissolve PAH and (ii) to quench DNA photocleavage. The presence of $\mathrm{Fe}^{3+}$ and $\mathrm{Zn}^{2+}$ enhances, while the presence of $\mathrm{Ca}^{2+}$ and $\mathrm{Mn}^{2+}$ inhibits the DNA photocleavage caused by 1-aminopyrene and UVA light. Other metal ions have minimal effect. This means that the effect of ions on DNA
\end{abstract}


photocleavage by PAHs is complex. The presence of KI enhances DNA photocleavage. This indicates that the triplet-excited state of 1-aminopyrene is involved in causing DNA cleavage.

Keywords: PAHs, 1-aminopyrene,1-hydroxypyrene, pyrene, solvents, photo-induced DNA damages, biologically relevant ions.

\section{Introduction}

Polycyclic aromatic hydrocarbons (PAHs) are widespread environmental pollutants that are produced during forest fire, volcanic eruption, incomplete burning of fuel and other materials, and as well as during tobacco smoke, and food processing [1,2]. Chemical carcinogenesis studies of these compounds started in 1915 when Yamagawa and Ichikawa observed that repeated application of coal tar on rabbits over extended periods induced skin carcinomas on the rabbit ears [3]. The first pure chemical carcinogen was recognized in 1930 when Kennaway and Hiegar synthesized dibenz $[a, h]$ anthracene and determined its carcinogenicity [4]. It was found that the fluorescence spectrum of dibenz $[a, h]$ anthracene did not correspond exactly to that of the carcinogenic components of coal tars. The investigation of other carcinogenic components of coal tar by Cook et al led to the discovery of benzo $[a]$ pyrene as a major carcinogenic component [5]. Since these pioneering studies, more than 30 parent PAHs and several hundred of their alkyl derivatives have been reported to exhibit some carcinogenic effects [6-10]. In addition, it has been shown that at least $75 \%$ of the total carcinogenic effect of condensates from exhausts of gasoline and diesel engines, coal combustion, and cigarette smoke can be attributed to PAHs containing four or more rings [11]. The epidemiological evidence of cancer risk from occupations such as chimney sweeps, aluminum workers, coke oven and coal gasification workers, iron and steel foundry workers, and asphalt and tar workers, however, shows that carcinogenicity is very likely to be caused, at least in part, by PAHs [2, 8, 9, 12-15].

PAHs, due to their extended aromatic ring systems, can absorb UVA $(320-400 \mathrm{~nm})$ and some of which can absorb visible light [16]. Upon absorbing light energy, the excited state PAH molecules can either give up their energy by emitting light (fluoresce) or heat, or react with surrounding molecules. Thus, PAHs in the cell may react with cellular molecules and cause toxic effects upon absorption of light. Indeed, it has been found that the combination of light and PAHs are more toxic to a variety of aquatic organisms than PAH themselves or light alone [17-21]. Our previous investigations have shown that the combination of PAHs and UVA light can cause DNA damages, such as single strand cleavage and formation of covalent PAH-DNA adducts [17, 22-26]. From these research findings, it seems that PAHs can be activated by light to cause toxic reactions with biological targets, in addition to metabolic activation. 


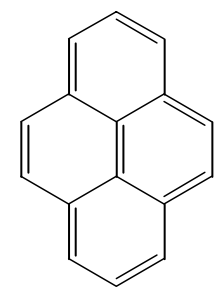

Pyrene

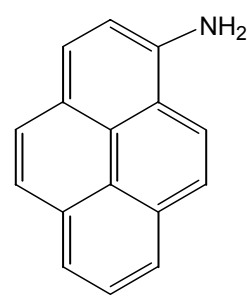

1-Aminopyrene (1-AP)

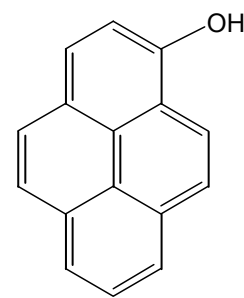

1-Hydroxypyrene (1-HP)

There are many molecules such as biologically important ions and organic molecules that coexist with PAHs in the cell. All these molecules could affect the ability of PAHs to cause damages to cellular components. It has been shown that the presence of histidine can enhance the 1-hydroxypyrene induced DNA photocleavage [22]. In this article, we report the effect of organic solvents methanol $(\mathrm{MeOH})$, dimethylformamide (DMF), and dimethylsulfoxide (DMSO) and biologically relevant ions, $\mathrm{Na}^{+}, \mathrm{Mg}^{2+}, \mathrm{Ca}^{2+}, \mathrm{K}^{+}, \mathrm{Fe}^{3+}, \mathrm{Cu}^{2+}, \mathrm{Zn}^{2+}, \mathrm{Mn}^{2+}$, and $\mathrm{I}^{-}$, on the light-induced DNA single strand cleavage by PAHs. The PAHs chosen are pyrene (P), 1-aminopyrene (1-AP), and 1-hydroxypyrene (1-HP). Pyrene is one of the most abundant PAHs in the environment and is not very water-soluble $[2,12,15]$. The presence of a hydroxy or an amino group enhances pyrene's water solubility and changes its electronic properties.

\section{Materials and Methods}

\section{Reagents, chemicals, and instrumentation}

Pyrene, 1-aminopyrene, and 1-hydroxypyrene were purchased from Aldrich Chemical Company (Milwaukee, WI) and used without further purification. Stock solutions $(1 \mathrm{mM})$ were prepared in $\mathrm{MeOH}, \mathrm{DMSO}$, or DMF, and stored in brown containers in the refrigerator. It was diluted with other solvents necessary to make the working solutions before use. ФX174 DNA (80-90\% supercoiled RF-1 or sc-DNA) with a molecular weight of $3.6 \times 10^{6}$ Da and 5386 bp was purchased from Promega Corporation (Madison, WI) and stored at $-20^{\circ} \mathrm{C}$. Ethidium bromide, bromophenol blue, xylencyanol, sodium chloride $(\mathrm{NaCl})$, potassium iodide $(\mathrm{KI})$, magnesium chloride $\left(\mathrm{MgCl}_{2}\right)$, manganese chloride $\left(\mathrm{MnCl}_{2}\right)$, zinc chloride $\left(\mathrm{ZnCl}_{2}\right)$, cupric chloride $\left(\mathrm{CuCl}_{2}\right)$, and ferric chloride $\left(\mathrm{FeCl}_{3}\right)$, were purchased from Sigma-Aldrich. Agarose, calcium chloride $\left(\mathrm{CaCl}_{2}\right)$, mono and dibasic sodium phosphate, TRISbase, boric acid, and EDTA were purchased from Fisher Scientific. All solvents used were spectroscopic grade. The water used (18 M $\Omega$ ) was deionized by a Barnstead Nanopure Infinity water deionization system (Dubuque, Iowa).

Light-induced DNA single strand cleavage by PAHs in the presence of biologically relevant ions and in various organic solvents

UVA-light induced plasmid DNA cleavage experiments were performed as following: Solutions (a total of $60 \mu \mathrm{L}$ for each sample buffered with $10 \mathrm{mM}$ sodium phosphate at $\mathrm{pH} 7.1$ ) containing $\Phi \mathrm{X}-174$ 
Phage DNA (27 $\mu \mathrm{M}$ in base pairs), $0.6 \mu \mathrm{M}$ 1-HP (6 $\mu \mathrm{M}$ 1-AP or $60 \mu \mathrm{M}$ pyrene) with $0.5,2,4,6,8,10$, 15 and $20 \%$ of an organic solvent were filled into the wells of a $3 \times 8$ flat-bottomed Titertek ${ }^{\mathrm{TM}}$ plate (ICN Biochemicals). It was not possible to get an organic solvent free solution because the PAH stock solution was made in an organic solvent and was diluted by aqueous buffer before use. The lowest organic solvent content can be achieved was $0.5 \%$. The rationale for using $0.6 \mu \mathrm{M} 1-\mathrm{HP}, 6 \mu \mathrm{M} 1-\mathrm{AP}$, or $60 \mu \mathrm{M}$ pyrene is that around $35 \%$ of the phage DNA will become the relaxed form after $1 \mathrm{~h}$ of irradiation in the presence of these concentrations of chemicals [17, 24]. If there is an inhibition or enhancement of the DNA photocleavage, it can be easily observed at this DNA cleavage range.

The Titertek plate was tightly covered with glass and placed onto a Pyrex glass support/filter, which was placed on an O-ring secured on a ring stand. The Pyrex glass served as a light filter to efficiently cut off any light below the wavelength of $300 \mathrm{~nm}$ that could damage DNA. The absorbance of the Pyrex glass was checked on the Varian CARY $300 \mathrm{UV}-\mathrm{Vis}$ spectrophotometer. Over $98 \%$ of light below the wavelength of $300 \mathrm{~nm}$ was filtered off. A 100 W UVA lamp (type B, UVP Inc., Upland, CA) was placed beneath the Pyrex glass and the light was applied through the bottom of the Titertek plate from a fixed distance of $6.5 \mathrm{~cm}$. The UVA intensity of the light output was measured to be $170 \mathrm{~J} / \mathrm{cm}^{2}$ per hour (UVA detector, Model PMA 2100, Solar Light Co., Inc., Philadelphia, PA). A stream of cold air blowing through the bottom of the Pyrex glass was used to eliminate any heat generated by the light source. The samples were irradiated for 1 hour and the titertek plate was turned four times during the irradiation to eliminate light heterogeneity. Three control experiments were used: (1) DNA with 10\% organic solvent without UVA irradiation, (2) DNA with $60 \mu \mathrm{M}$ pyrene $(0.6 \mu \mathrm{M} 1$ 1-HP or $6 \mu \mathrm{M}$ 1-AP) and $10 \%$ organic solvent without irradiation, and (3) DNA $+10 \%$ organic solvent irradiated for $1 \mathrm{~h}$ as the other samples.

After irradiation, $12 \mu \mathrm{L}$ of a gel-loading dye solution (bromophenol blue and xylencyanol in 50\% glycerol) was added into each well and mixed. Then $14 \mu \mathrm{L}$ of the sample was loaded into the wells of a pre-prepared $1 \%$ agarose gel. The gel was run in $1 \times \mathrm{TBE}$ buffer $(\mathrm{pH}=8.27)$ at 80 volts for $80 \mathrm{~min}$ at room temperature. Following electrophoresis, the gel was stained with ethidium bromide $(2 \mathrm{mg} / \mathrm{L})$ for 90 min and analyzed with a NucleoVision Gel-Documentation System (Nucleo Tech Inc., CA). In the gel, there are two clear bands with the supercoiled form I DNA being the band further away from the origin and the relaxed form II DNA closer to the origin. This is because that both forms of DNA have the same molecular weight and charge, but have different size. The relaxed form II is larger than the supercoiled form I DNA. Therefore, the smaller in size will move faster in the electric field under gel electrophoresis conditions. The amount of the supercoiled Form I DNA and the relaxed open circular Form II DNA were quantified by the total fluorescence intensity of the bands after subtracting a common background as before [17]. Then the percent of supercoiled DNA that is changed to the relaxed form is calculated. Based on previous experiments, a $\pm 20 \%$ error is usually observed for percent DNA cleavage due to differences in light dose for each well, uncertainties in quantification of the fluorescence intensity of the band. 
In the same way, the solutions (a total of $60 \mu \mathrm{L}$ for each sample) containing $\Phi X 174$ DNA (27 $\mu \mathrm{M}$ in base pairs) and $6 \mu \mathrm{M}$ of 1 -AP in $10 \%$ methanol with $10 \mathrm{mM}$ sodium phosphate ( $\mathrm{pH} 7.1$ ), with a certain concentrations of a biologically relevant ion were filled into the wells of a 24 well $(3 \times 8)$ flat-bottomed Titertek $^{\mathrm{TM}}$ plate and irradiated and subjected to gel-electrophoresis.

\section{Solubility tests}

UV absorption spectra of pyrene $(60 \mu \mathrm{M}), 1$-AP $(20 \mu \mathrm{M})$ and 1-HP $(20 \mu \mathrm{M})$ were used to monitor the solubility of these compounds. A concentration of $60 \mu \mathrm{M}$ of pyrene solutions in $2,4,6,8,10,15$, $20 \%$ of methanol, DMF, or DMSO were prepared and their UV absorption spectra were recorded to monitor the solubility of pyrene. The use of $60 \mu \mathrm{M}$ pyrene was because this was the concentration used for the DNA photocleavage experiments. The concentration of $20 \mu \mathrm{M}$ for 1-AP and 1-HP was much higher than the concentrations for 1-AP $(6 \mu \mathrm{M})$ and 1-HP $(0.6 \mu \mathrm{M})$ used for the DNA cleavage experiment. It was for a high enough absorption to be easily detected by instrument.

\section{Results and Discussion}

\section{Solubility of pyrene, 1-AP, and 1-HP in methanol, DMF, and DMSO}

It is known that pyrene's solubility in water is $0.64-0.73 \mu \mathrm{M} / \mathrm{L}[27,28]$. Although it is not available, a much better water solubility for 1-AP and 1-HP is expected due to the presence of a polar amino or hydroxy group, respectively. The absorption spectra of 1-AP and 1-HP $(20 \mu \mathrm{M})$ in 2 to $20 \%$ of an organic solvent (MeOH, DMF, or DMSO) do not change significantly due to the change of the organic solvent contant. This means that both compounds dissolve well in the $2 \%$ or up of the mixed solvents. Since this concentration is higher than the actual concentration of these two compounds used for the DNA cleavage experiments $(0.6 \mu \mathrm{M}$ for $1-\mathrm{HP}$ and $6 \mu \mathrm{M}$ for $1-\mathrm{AP})$, it is safe to say that both 1 AP and 1-HP are fully dissolved in the solvent used. However, pyrene does not dissolve very well in 2$20 \%$ of the organic solvents. Based on pyrene's solubility, only very small amount of the $60 \mu \mathrm{M}$ pyrene can dissolve in pure water (most of them stay in the solid phase). Therefore, it is safe to assume that only sparing amount of pyrene may dissolve in aqueous solutions containing 2, 4, 6, 8,10, $15,20 \%$ of methanol, DMF, or DMSO. The absorption intensity at $335 \mathrm{~nm}$ of the dissolved pyrene in $2,4,6,8,10,15,20 \%$ of methanol, DMF, or DMSO constantly increased when the amount of the organic solvent increases. If $50 \%$ of the organic solvent is used, pyrene seems fully dissolved and the absorption band at $335 \mathrm{~nm}$ for pyrene in $2 \%$ organic solvent shifts slightly to the blue at $333 \mathrm{~nm}$.

\section{Effect of methanol, DMF, and DMSO on the light-induced DNA cleavage by PAHs}

The effect of solvent DMSO on the light induced DNA cleavage by 1-AP is shown in Figure 1 with the gel picture on the bottom and the bar graph representing the percent of DNA cleavage on the top. 


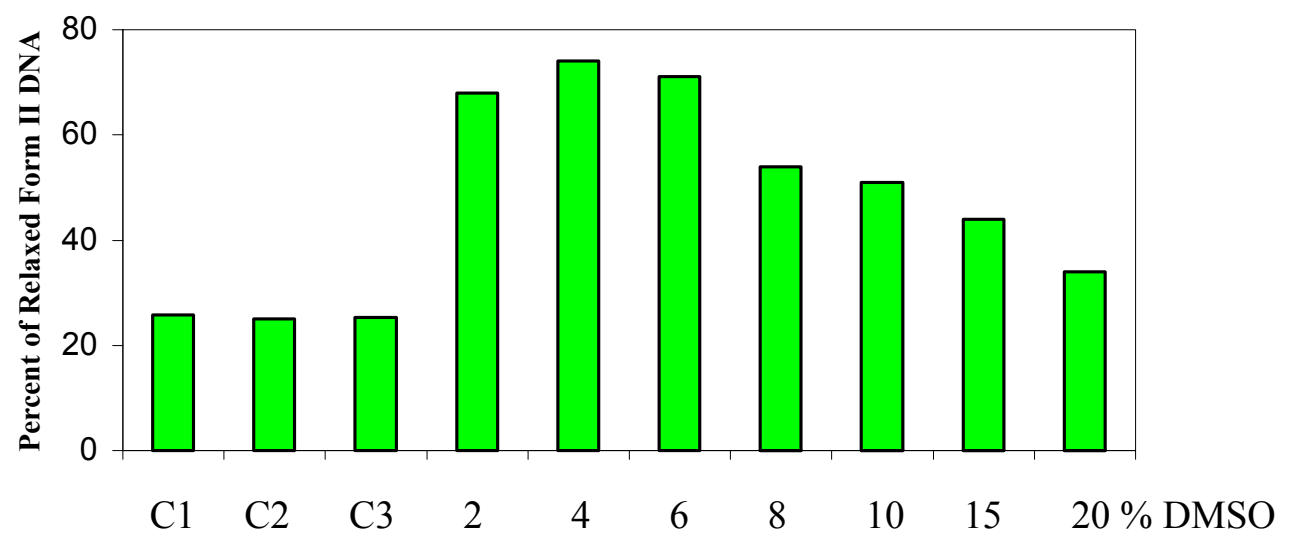

Relaxed DNA

Supercoiled DNA

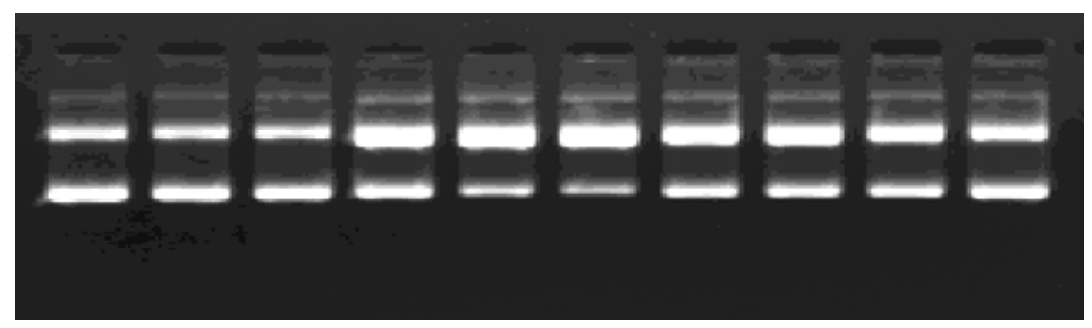

Figure 1. Effect of DMSO on light-induced DNA cleavage by 1-Aminopyrene (1-AP). All lanes contain $27 \mu \mathrm{M}$ supercoiled plasmid $\Phi$ X174 DNA and vairious percent of DMSO and irradiated for $1 \mathrm{hr}$ with a UVA $\operatorname{lamp}(170 \mathrm{~J} / \mathrm{cm} / \mathrm{h})$. The original plasmid DNA has about $25 \%$ relaxed form as shown in the control lanes $\mathrm{C} 1, \mathrm{C} 2$, and $\mathrm{C} 3$. $\mathrm{C} 1: 10 \% \mathrm{DMSO}$, no irradiation; $\mathrm{C} 2: 10 \% \mathrm{DMSO}+6 \mu \mathrm{M} 1-$ AP, no irradiation; $\mathrm{C} 3: 10 \%$ DMSO, $1 \mathrm{~h}$ irradiation.

As one can see, supercoiled DNA is converted to relaxed DNA in lanes containing 2-20\% DMSO and $6 \mu \mathrm{M}$ 1-AP irradiated for $1 \mathrm{~h}$. As DMSO concentration increases, the amount of relaxed DNA increases slightly (from $2 \%$ to $6 \%$ ) then decreases.After converting percent of relaxed DNA to percent of DNA cleavage as before [17], the percent of DNA single strand cleavage is plotted against the percent of an organic solvent used during the DNA photocleavage experiment (Figure 2). In Figure 2, panels $\mathrm{A}, \mathrm{B}$ and $\mathrm{C}$ plot the effect by $\mathrm{MeOH}, \mathrm{DMF}$, and $\mathrm{DMSO}$, respectively, on the DNA photocleavage by all three compounds. The DNA photocleavage data carry relatively large errors (20\%) as described in the experimental section and in previous publications $[17,24]$. All three organic solvents behave similarly for 1-AP and 1-HP: it looks that the percent of DNA photocleavage caused by 1-HP or 1-AP constantly decreases as the organic solvent content increases. Since both compounds are fully dissolved in these solvent mixtures, the decrease in DNA photocleavage must be due to quenching by the organic solvent. Fitting the photocleavage data to a linear equation, the slopes of the plots are obtained for 1AP: 1.9 (DMSO), 1.8 (DMF), 1.5 (MeOH) and for 1-HP: 3.0 (DMF), 2.1 (DMSO), 1.3 (MeOH). For both compounds, $\mathrm{MeOH}$ has the smallest effect on the light-induced DNA cleavage and the other two organic solvents have similar effect. It is known that DNA photocleavage by 1-HP is due to both singlet oxygen and free radicals [24]. The hydrogen atoms of the methyl group in the organic solvents $\mathrm{MeOH}, \mathrm{DMF}$, and DMSO may react with the free radical intermediates and inactivate the free radical, thus, preventing the free radicals to react with DNA molecules and cause damages. 

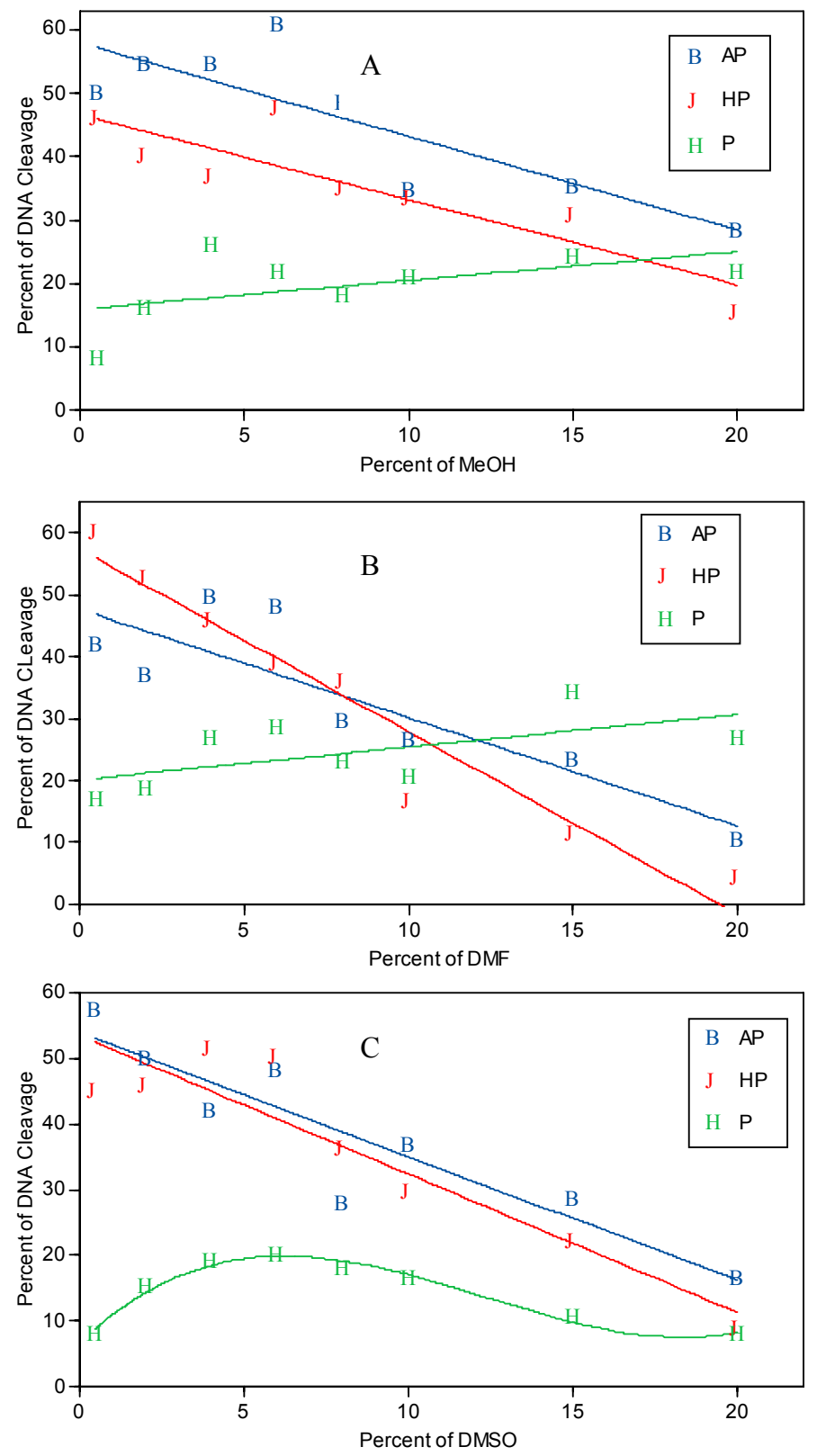

Figure 2. Effect of organic solvents on the percent of DNA photocleavage induced by 1-aminopyrene (AP, $6 \mu \mathrm{M})$, 1-hydroxypyrene (HP, $0.6 \mu \mathrm{M})$ and pyrene $(\mathrm{P}, 60 \mu \mathrm{M})$. The solvents are with a certain percentage of methanol (MeOH, panel A), dimethylformamide (DMF, panel B) and dimethylsulfoxide (DMSO, panel C) in $10 \mathrm{mM}$ phosphate buffer at $\mathrm{pH}$ 7.0. The error for each point is about $\pm 20 \%$. The straight lines are best linear fits of the data except for pyrene in DMSO, which was just a smooth line connecting of all the data points.

In contrast, the DNA photocleavage caused by pyrene and light steadily increases as the amount of the organic solvent increases up to $20 \%$ organic solvent. The increase for pyrene-induced DNA photocleavage by the increase of an organic solvent should be due to the increased concentration for dissolved pyrene with the increase of the amount of the organic solvent. With DMSO, the DNA photocleavage increases as the DMSO percentage increases till about $6 \%$, followed by a decrease. 
Therefore, the presence of an organic solvent can cause two folds of effect on the DNA photocleavage by PAHs: (1) to increase the solubility of PAHs, thus increase the effective concentration of the compounds to undergo photoreaction; (2) the presence of an organic solvent can quench the lightinduced DNA cleavage. The slight decrease for DNA photocleavage in the presence of $>8 \%$ DMSO must mean that the quenching effect by DMSO out-weigh the solubility effect.

\section{Effect of ions on photocleavage of DNA by 1-AP}

DNA photocleavage induced by the combination of 1-AP and light were also carried out in the presence of biologically relevant ions. The choice of the chloride salt was to eliminate any effect from the anion. Figure 3 shows the effect of the ions on DNA photocleavage by $6 \mu \mathrm{M} 1$-AP. All experiments were carried out with $27 \mu \mathrm{M}$ DNA and $6 \mu \mathrm{M}$ 1-AP, and the mixture was irradiated for $1 \mathrm{~h}$. The control experiment (column 1) shows that 1-AP can induce DNA cleavage upon UVA light irradiation. In the presence of $50 \mathrm{mM} \mathrm{NaCl}$ and $\mathrm{MgCl}_{2}$, the percent of DNA photocleavage decreases slightly, which may not be significant considering experimental errors can be as high as $20 \%$. In the presence of $\mathrm{CaCl}_{2}$ and $\mathrm{MnCl}_{2}$, the inhibition of DNA photocleavage is more obvious, especially with $\mathrm{MnCl}_{2}$, the photocleavage induced by light and 1-AP almost diminished. In the presence of $5 \mathrm{mM} \mathrm{CuCl}_{2}$, there is a $13 \%$ increase of DNA photocleavage. Again this could be due to error. However, in the presence of $5 \mathrm{mM} \mathrm{ZnCl}_{2}$, a marked increase $(65 \%)$ for the amount of DNA cleavage is observed. With $\mathrm{Fe}^{3+}$ the increase is $168 \%$ (data not shown). This is because the presence $\mathrm{Fe}^{3+}$ alone can also cause DNA single strand cleavage from a separate experiment. Therefore, it is obvious that the effect by alkali ions on the

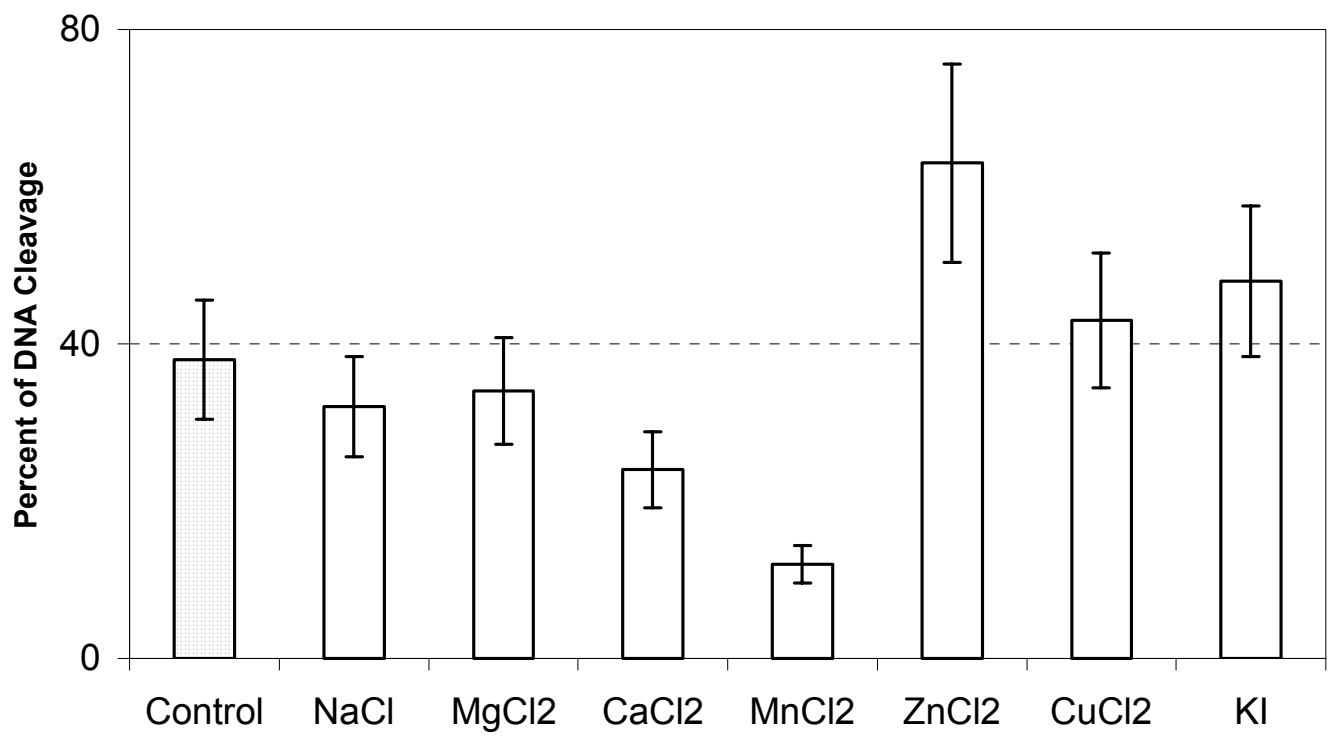

Figure 3. Effect of biologically relevant ions on UVA-induced DNA cleavage by $6 \mu \mathrm{M}$ 1-AP in 10 $\mathrm{mM}$ sodium phosphate buffered solution with $10 \% \mathrm{MeOH}$. Errors for $\%$ of DNA cleavage are usually $<20 \%$. The concentration of ions used are $50 \mathrm{mM}$ for $\mathrm{NaCl}, \mathrm{KI}, \mathrm{MgCl}_{2}$ and $\mathrm{CaCl}_{2}$ and $5 \mathrm{mM}$ for $\mathrm{MnCl}_{2}, \mathrm{ZnCl}_{2}$, and $\mathrm{CuCl}_{2}$. 
photocleavage of DNA by 1-AP is negligible. However, depending on the transition metals present, they may either enhance or inhibit DNA photocleavage by 1-AP. At this point it is not known why some ions enhance and some inhibit DNA photocleavage.

The presence of KI can slightly enhance DNA cleavage. Although it is not obvious from the graph, repeated experiments have shown that the presence of $50 \mathrm{mM} \mathrm{KI}$ does cause more of the supercoiled DNA to convert to relaxed DNA. This is opposite to the effect by KI on the 1-HP induced DNA photocleavage where KI inhibits DNA cleavage [24]. Mechanistically speaking, the 1-HP induced DNA cleavage is due to the excited singlet state of 1-HP. Since it is known that iodide ion (heavy atom) can increase the intersystem crossing yield to convert singlet excited molecule to triplet excited molecule, it can be assumed that it is the triplet excited state of 1-AP that participates in inducing DNA.

\section{Conclusions}

In conclusion, both the presence of an organic solvent and some of the ions examined have a significant effect on the light induced DNA cleavage by 1-HP, 1-AP, and pyrene. The organic solvents can serve as both a media to enhance PAHs solubility or can act as a quencher of the DNA photocleavage by PAHs. The quenching effect varies, with DMSO and DMF being the stronger and methanol the weaker quencher. The effect on DNA photocleavage by DMSO and DMF are about the same. The effect by ions on the DNA photocleavage is complex, with $\mathrm{Ca}^{2+}$ and $\mathrm{Mn}^{2+}$ quenching and $\mathrm{I}^{-}, \mathrm{Fe}^{3+}$, and $\mathrm{Zn}^{2+}$ enhancing the photocleavage of DNA by 1-AP. This observation should have to do with how the individual ions would affect (i) the excited-states of the PAHs and (ii) the reactive intermediates (reactive oxygen species or free radicals), and (iii) how they themselves interact with the PAHs or DNA chemically and physically. Therefore, evaluation of PAH phototoxicity on a molecular level is a complex issue since PAHs coexist with many other ions and chemicals in the cell that can affect their ability to cause cellular damages.

\section{Acknowledgements}

This research was supported by the National Institutes of Health through generous grants: NIH-RCMI G12RR13459-01 and NIH-SCORE S06GM08047 and the Army Research Office: DAAD 19-01-10733 to JSU.

\section{References}

1. Baum, E., Occurrence and surveillance of polycyclic aromatic hydrocarbons. In Polycyclic Aromatic Hydrocarbons and Cancer Gelboin, H., and Ts'O, T., Eds, 1978, Vol. 1, pp. 45-70, Academic Press, New York.

2. Connell, D. W., Hawker, D. W., Warne, M. J., and Vowles, P. P., Polycyclic aromatic 
hydrocarbons (PAHs). In Introduction into Environmental Chemistry (McCombs, K., and Starkweather, A. W., eds), 1997, pp. 205-217, CRC Press LLC, Boca Raton, FL.

3. Pitot, H. C., Mechanisms of Chemical Carcinogenesis: Theoretical and Experimental Bases. In Chemical Carcinogenesis and Mutagenesis I. Handbook of Experimental Pharmacology (Cooper, C. S., and Growler, P. L., eds), 1990, Vol. 94/I pp. 2-29, Springer-Verlag, London.

4. Kennaway, E. L., and Hieger, I., Carcinogenic substance and fluorescence spectra. Brit. Med. J., 1930, $1,1044-1046$.

5. Cook, J. W., Hewett, C. L., and Hieger, I., The isolation of a cancer producing hydrocarbon from coal tar. J. Chem. Soc., 1933, 395-405.

6. Angerer, J., Mannschreck, C., and Gundel, J., Biological monitoring and biochemical effect monitoring of exposure to polycyclic aromatic hydrocarbons. Int. Arch. Occup. Environ. Health, 1997, 70, 365-377.

7. Harvey, R. G., Polycyclic Aromatic Hydrocarbons: Chemistry and Carcinogenicity, 1991, Cambridge University Press, London.

8. Hemminski, K., Grzybowska, E., Chorazy, M., Twardowska-Saucha, K., Sroczynski, J. W., Putman, K. L., Randrath, K., Phillips, D. H., Hewer, A., Santella, R. M., and Perera, F. P., DNA adducts in humans related to occupational exposure to aromatic compounds. In Complex Mixtures and Cancer Risk (Vainio, H., Sorsa, M., and McMichael, A. J., eds), 1990, Vol. 104 pp. 181-192, IARC Scientific Publisher, Lyon, France.

9. Bjorseth, A., and Becher, G., PAH in work atmospheres: Occurence and determination, 1986, Boca Raton, FL.

10. Bjorseth, A., and Ramdahl, T., Emission source and recent progress in analytical chemistry Vol. 2, 1985, Marcel Dekker, New York.

11. Grimmer, G., Brune, H., Dettbarn, G., Jacob, J., Misfeld, J., Mohr, U., Nanjack, K., Timm, J., and Wenzel-Hartung, R., Relevance of polycyclic aromatic hydrocarbons as environmental carcinogens. Fresnius J. Anal. Chem., 1991, 339, 792-792.

12. IARC, Polynuclear aromatic compounds. Part I: Chemical, Environmental and Experimental Data, 1983, International Agency for Research on Cancer, Lyon.

13. Bleeker, E. A., Wiegman, S., de Voogt, P., Kraak, M., Leslie, H. A., de Haas, E., and Admiraal, W., Toxicity of azaarenes. Rev. Environ. Contam. Toxic., 2002, 173, 39-83.

14. Hemminki, K., Koskinen, M., Rajaniemi, H., and Zhao, C., DNA adducts, mutations, and cancer 2000. Regul. Toxicol. Pharmacol., 2000, 32, 264-275.

15. Shaw, G. R., and Connell, D. W., Prediction and monitoring of the carcinogenicity of polycyclic aromatic compounds (PACs). Rev. Environ. Contam. Toxic., 1994, 135, 1-62.

16. Dabestani, R., and Ivanov, I. N., A comparison of physical, spectroscopic and photophysical properties of polycyclic aromatic hydrocarbons. Photochem. Photobiol, 1999, 70, 10-34.

17. Dong, S., Hwang, H.-M., Harrison, C., Holloway, L., Shi, X., and Yu, H., UVA light-induced DNA cleavage by selected polycyclic aromatic hydrocarbons. Bull. Environ. Contam. Toxicol., 2000, 64, 467-474.

18. Huang, X.-D., Dixon, D. G., and Greenberg, B. M., Impact of UV radiation and photomodification 
on the toxicity of PAHs to the higher plant Lemna gibba (Duckweed). Envin. Toxicol. Chem., 1993, 12, 1067-1077.

19. Huang, X.-D., Krylov, S. N., Ren, L., McKonkey, B. J., Dixon, D. G., and Greenberg, B. M., Mechanistic quantitative structure-activity relationship model for the photoinduced toxicity of polycyclic aromatic hydrocarbons: II. An empirical model for the toxicity of 16 polycyclic aromatic hydrocarbons to the duckweek lemna gibba L. G-3. Environ. Toxicol. Chem., 1997, 16, 2296-2303.

20. Pelletier, M. C., Burgess, R. M., Ho, K. T., Kuhn, A., McKinney, R. A., and Ryba, S. A., Phototoxicity of individual polycyclic aromatic hydrocarbons and petroleum to marine invertebrae lavae and juveniles. Envin. Toxicol. Chem., 1997, 16, 2190-2199.

21. Arfsten, D. P., Schaeffer, D. J., and Mulveny, D. C., The effects of near ultraviolet radiation on the toxic effects of polycyclic aromatic hydrocarbons in animals and plants: A review. Ecotoxicol. Environ. Safety, 1996, 33, 1-24.

22. Dong, S., Fu, P. P., Hwang, H.-M., and Yu, H., Effects of histidine on light-induced DNA single strand cleavage by selected polycyclic aromatic hydrocarbons. Polycycl. Arom. Compd., 2002, In press.

23. Dong, S., Fu, P. P., Shirsat, R. N., Hwang, H.-M., Leszczynski, J., and Yu, H., UVA light-induced DNA cleavage by isomeric methylbenz[a]anthracenes. Chem. Res. Toxicol., 2002, 15, 400-409.

24. Dong, S., Hwang, H.-M., Shi, X., Holloway, L., and Yu, H., UVA-induced DNA single strand cleavage by 1-hydroxypyrene and formation of covalent adducts between DNA and 1hydroxypyrene. Chem. Res. Toxicol., 2000, 13, 585-593.

25. Yu, H., Dong, S., Fu, P. P., and Hwang, H.-M., UVA light-induced DNA single strand cleavage by hydroxybenzo[a]pyrenes. Polycycl. Arom. Compd., 2002, In press.

26. Hwang, H.-M., Shi, X., Ero, I., Jayasinghe, A., Dong, S., and Yu, H., Microbial ecotoxicity and mutagenicity of 1-hydroxypyrene and its photoproducts. Chemosphere, 2001, 45, 445-451.

27. Kochany, J., and Maguire, R. J., Abiotic transformations of polynuclear aromatic hydrocarbons and polynuclear aromatic nitrogen heterocycles in aquatic environments. Sci. Total Environ., 1994, 144, 17-31.

28. Mackay, D., and Shiu, W. Y., Aqueous solubility of polynuclear aromatic hydrocarbons. J. Chem. Eng. Data, 1977, 22, 399-402.

(C) 2002 by MDPI (http://www.mdpi.org). 